\title{
DEĞERLENDİRME MAKALESİ
}

\author{
SASANI TARİH \\ YAZIMINDA PARADİGMA \\ MESELESI, YENI VERILER \\ VE YENI UFUKLAR
}

\author{
Turhan Kaçar \\ İstanbul Medeniyet Üniversitesi \\ turhan.kacar@medeniyet.edu.tr \\ ORCID: 0000-0002-4071-7538 \\ DOI: $10.20519 /$ divan.614165
}

\begin{abstract}
Parvaneh Pourshariati. Decline and Fall of the Sasanian Empire, The Sasanian-Parthian Confederacy and the Arab Conquest of Iran. Londra: I. B. Tauris, 2008. xiv + 536 sayfa.

Eberhard W. Sauer, ed. Sasanian Persia, Between Rome and the Steppes of Eurasia. Edinburgh: Edinburgh University Press, 2017. xxii + 314 sayfa.

Khodadad Rezakhani. ReOrienting the Sasanians, East Iran in Late Antiquity. Edinburgh: Edinburgh University Press, 2017. xiv +242 sayfa.
\end{abstract}

Rahmetli Halil İnalcık Has-bağçede 'Ayş u Tarab, Nedîmler Şâîler Mutrîbler (İstanbul: Türkiye İş Bankası Kültür Yayınları, 2011) adlı eserinin giriş bölümünde, Ortaçağ İslam dünyasının (ve elbette daha sonra Osmanlıların) kültürleşme sürecinde İran'ın çok önemli rolüne dikkat çekmektedir. Bu tespit, Geç Antikçağ tarih yazıcılığında, İslam dünyasının kültürel katmanları arasında tarihsel süreklilik adına fazlasıyla öne çıkarılan klasik Yunan-Roma kültürel birikimini dengelemesi açısından da çok önemlidir. Ortaçağ İslam dünyasını derinden etkileyen Şâhnâme, Kâbûsnâme, Siyâsetnâme 
gibi eserler sundukları tarihsel malzemeyi çoğunlukla Sasani tarihinden aldıkları için, söz konusu dönemin tarihi, kültürü, dinî ve sosyal yapısı daha yakından ele alınmayı hak etmektedir. Sasani dönemi İran dünyasının kültürü ve yarattığı kurumları, Orta Asya'dan Akdeniz'e kadar çağdaşı olan geniş bir coğrafyayı etkilediği gibi, Ortaçağ İslam dünyasına ve sonraki dönemde Osmanlı kültürüne etkisi de pek iyi bilinen bir husustur. Bundan dolayıdır ki, Sasani tarihinin önemi, batı dünyasında layıkıyla fark edilmeye başlanmış ve İran tarihinin sadece batı kısmı değil doğu kısmı da ciddi araştırmaların konusu olmuştur ve olmaya da devam etmektedir. Aynı durum ne yazık ki Türkiye'deki tarihçilik için geçerli değildir. Eski İran edebiyatı ve mitolojisi üzerine Türkçe olarak yazılmış bazı çalışmalar bulmak mümkün ise $\mathrm{de}^{1}$ çok da profesyonel olmayan birkaç doktora tezi ve kısa makale dışında Sasani tarihi hakkında ciddi bir tarih literatüründen söz etmek pek mümkün değildir.

Halbuki Sasani İmparatorluğu, M.S. 224-642 arasında Maveraünnehir'den (İng. Transoxiana, Ceyhun ötesi) Fırat'a kadar uzanan geniş coğrafyada, sınırları neredeyse hiç değişmeden, dört yüz yıldan fazla bir süre bütün olarak ayakta kalmayı başarmış istisnai bir Antikçağ devletiydi. Erken Ortaçağ doğu dünyasını dikkate aldığımız zaman, Sasaniler uzun yaşamlarını, siyasi, askeri ve ekonomik olarak örgütlenmelerinin yanı sıra Zerdüştlük gibi çok belirgin bir dinî ideolojiye de borçluydular. Sasani coğrafyasını Mezopotamya ve İran platosu oluşturuyordu ve bu iki bölgeyi Zagros dağları ayırıyordu. Zirai imkanları geniş olan "Mezopotamya Sasanilerin iktisadi kalbiydi.” Richard Payne'nin önemli eserinin başlığının ifade ettiği gibi, Sasani İran'1, Zerdüştlerden ibaret gibi görünse de Hristiyanlar, Yahudiler ve diğer pagan kültleri de barındırıyordu. ${ }^{2}$ Diğer yandan Sasani tarihi, sikke dolaşımı ve iktisadi hayatın kontrolü, savunma yapıları ve kentleşme, sulama sistemlerinin geliştirilmesi ve tarımsal hayatın düzenlenmesi gibi pek çok açıdan bıraktığı arkeolojik miras ile tarih yazımının konusu olma meselesinde adeta kendisini dayatmaktadır.

1 Nimet Yıldırım, Fars Mitolojisi Sözlüğü (İstanbul: Kabalcı Kitabevi, 2008); Nimet Yıldırım, Iran Kültürü, Zerdüsst'ten Firdevsî'ye Sadî'den Şamlu'ya İran'ın Sözlü ve Yazılı Kaynakları (İstanbul: Pinhan Yayıncılık, 2016). Nimet Yıldırım ayrıca Firdevsî̉nin Şâhnâme'sinin tam bir çevirisini de yapmıştır.

2 Richard E. Payne, A State of Mixture, Christians, Zoroastrians and Iranian Political Culture in Late Antiquity (Oakland: University of California Press, 2015). 
Sasani dönemi üzerine tarih çalışmalarının kökeni Batı dünyasında XIX. yüzyılın son çeyreğine kadar geri gitmektedir. 1875'de Oxford Üniversitesi profesörlerinden George Rawlinson The Seventh Great Oriental Monarchy, or the Geography, History and Antiquities of the Sassanian or the New Persian Empire adl eserinin yazımını tamamladı. Bundan sadece birkaç yıl sonra ünlü Alman oryantalist Theodore Nöldeke, Taberi'nin Sasani tarihiyle ilgili cildini kapsamlı bir giriş ve açıklayıcı notlarla birlikte yayınladı. ${ }^{3}$ Ancak bu iki eser, Sasani tarihi üzerine daha kapsamlı çalışmalar için hemen bir zemin oluşturmadı. Danimarkalı İran dilleri ve kültürleri uzmanı Arthur Christensen, 1907 yılında Sasani devlet ve toplum yapısını ele aldığı L'empire des Sassanides. Le peuple, l'état, la cour adlı eserini yayınladı ve bu eser, genişletilmiş ikinci basımı 1944 yapılan L'Iran sous les Sassanides' in (Sâsânîler Döneminde Iran) temeli oldu.

Richard Frye'in The History of Ancient Iran (1984) ve çok kapsamlı bir akademik derleme olan Cambridge History of Iran (1983 ve 2000) Sasani tarihi için önemli bölümler içermekteyseler de Christensen'den sonra, Sasani tarihi ilk defa 1990 yılında Klaus Schipmann'ın Grundzüge der Geschichte des Sasanidischen Reiches eseriyle müstakil bir monografinin konusu oldu. Hiç şüphesiz çağdaşı Roma ve Bizans tarihi üzerine yapılan çalışmaların sayısıyla kıyas kabil değildir ama 2000’li yılların İran tarihçiliği için gerçekten bir "yükseliş" dönemi olduğu söylenebilir. ${ }^{4}$ Bu yükselişin gerisinde Peter Brown'un 1971'de yayınladığı ve Roma / Bizans tarih yazımının yönünü daha fazla Doğu Akdeniz'e çeviren The World of Late Antiquity vardır. ${ }^{5} \mathrm{Bu}$ eserin son bölümleri Sasanilerin dünyasının sadece Batı için değil Orta Asya için de önemini hatırlatmaktadır. Brown’un “Geç Antikçağ” olarak tanımladığı III-VIII. yüzyıllar

3 Theodor Nöldeke, Geschichte der Perser und Araber zur Zeit der Sasaniden, Aus der Arabischen Chronike des Tabari, Übersetzt und mit Ausführliche Erläuterungen und Ergänzungen Versehn (Leiden: Brill, 1879); Irfan Shahid, “Theodor Nöldeke’s ‘Geschichte Ders Perser Und Araber Zur Zeit Der Sasaniden': An Evaluation,” International Journal of Middle Eastern Studies 8 (1977): 117-22.

4 Sasani tarihi üzerine son yapılan kolektif çalışmalardan birisi de I. Hüsrev ve dönemini (531-579) arkeoloji, tarih, para basımı, hukuk sistemi, dinî yapısı, etnik kompozisyon ve tarih yazımı gibi çok farklı perspektiflerden ele almaktadır. Christelle Jullien, ed., Husraw Ier Reconstructions D'un Règne Sources et Documents (Paris: Peeters Publishers, 2015).

5 Peter Brown, Geç Antikçağ Dünyası, çev. Turhan Kaçar, 2. basım (İstanbul: Alfa Yayıncılık 2017).

\section{9}

Dîvân

$2019 / 1$ 
arası Sasani tarihinin tamamını kapsamaktadır. Roma / Bizans ve Sasaniler arasındaki karşılaştırmalı çalışmaların yanı sıra, ${ }^{6}$ Oxford Üniversitesi yayınları arasında İran tarihi üzerine çıkan iki el kitabı ve Touraj Daryaee'nin “bir giriş metni” niteliğindeki eseri dikkate değerdir. ${ }^{7}$ Touraj Daryaee'den kısa da olsa söz edilmelidir, çünkü çok üretken bir İranlı / İran tarihçisi olan Daryaee'nin herhangi bir çalışmasına atıf yapılmadan bugün Sasani tarihi yazmak neredeyse mümkün değildir. Başta Touraj Daryaee'nin kişisel web sayfası olmak üzere, günümüz dünyasında internette yer alan materyaller de göz önünde tutulmalıdır. Bu bağlamda, içerdikleri ikincil literatür ve ansiklopedik bilgiler bakımından, internet versiyonu da bulunan Encyclopedia Iranica (http:/ / www.iranicaonline.org), California Üniversitesi (Irvine) resmî web sayfasında yer alan Sasanika projesi, The Circle of Ancient Iranian Studies (CAIS, Eskiçağ İran Çalışmaları Grubu) gibi dijital kaynaklar dikkate değerdir.

Modern Sasani tarihi çalışmalarının vazgeçilmez referans ve hareket noktalarından birisi hiç şüphesiz Danimarkalı Arthur Christensen'dir. Selefleri Partlar'a göre, Sasanileri "güçlü merkeziyetçi bir devlet” olarak gören Christensen'in bu yaklaşımı, uzun zamandan beri bu alanın temel paradigmasıydı. Sasani tarihi çalışmalarında 2000'li yıllardaki yükselişin en önemli temsilcilerinden birisi olan Parvaneh Pourshariati Decline and Fall of the Sasanian Empire, The Sasanian-Parthian Confederacy and the Arab Conquest of Iran başlıklı eserinde Christensen'in yaklaşımını açıkça reddetmektedir. Sasani İmparatorluğu'nun çöküşünü “konfederatif devlet” yapısıyla açıklayan Pourshariati, görünüşte çok güçlü ve iyi idare edildiği düşünülen Sasani devletinin, Müslüman Arap saldırıları karşısında nasıl bu kadar hızlı çöktügü sorusunun cevabını aslında başlıkta vermektedir. Gerçekten de nihai çöküşünden sadece on beş yıl önce, 626 yılında Boğaz'ın Anadolu yakasında Chrysopolis'te (Üsküdar) konuşlanmış bir Sasani ordusu, karşı k1yıdaki Bizanslılara korku salıyordu. Ancak Sasaniler izleyen iki yıl içerisinde Bizanslılara karşı giriştikleri bilek güreşini veya yaygın nitelemeyle "Antikçağın son büyük savaşını" kaybettiler. Bunu iz-

6 Mesela: Matthew P. Canepa, The Two Eyes of the Earth: Art and Ritual of Kingship Between Rome and Sasanian Iran (Berkeley: University of California Press, 2009).

7 Touraj Daryaee, The Oxford Handbook of Iranian History (Oxford: Oxford University Press, 2012); Touraj Daryaee, Sasanian Persia, The Rise and Fall of an Empire (Londra: I. B. Tauris, 2009); Daniel T. Potts, The Oxford Handbook of Ancient Iran (Oxford: Oxford University Press, 2013). 
leyen yıllarda önce iç istikrar ve sonra da Müslüman Arap saldırıları karşısında bütün imparatorluk çöktü. Daha önce herhangi bir süper güçle boy ölçüşmemiş Arapların, 638 ve 642 'deki iki savaşta Sasanileri yenmeleri ve son kral III. Yezdigerd'in 651 yılında ölümüyle birlikte Sasani devletinin tamamen tasfiye edilmesi, çağının insanları için çok şaşırtıcı olmalıydı.

Pourshariati'nin 500 sayfayı aşan devasa eseri, problematiği “siyasi tarih" ve "dinî akımlar" başlıklı iki temel kısım üzerinde ve bunları oluşturan altı alt bölümde kurgulamaktadır. İran tarihinin Part arka planını kısa bir bölümde özetleyen Pourshariati, ikinci bölümde Part-Sasani konfederatif devlet yapısını ele almakta, üçüncü bölümde ise İran'daki Arap fetihlerinin başarısını araştırmaktadır. Dördüncü bölümde Part-Sasani konfederasyonunu oluşturduğunu düşündüğü Taberistan bölgesindeki güçlü hanedan-ailelerin durumu incelenmektedir. Eserin, "dinî akımlar" başlıklı ikinci kısmının, konunun esasıyla ilgisi olmadığı belirtilmelidir, çünkü Pourshariati beş ve altıncı bölümlerde Part ve Sasani kökenli hanedan-ailelerdeki dinî gelenek ve kurum farklılaşmasının, Müslüman-Arap akınlarını nasıl kolaylaştırdığı sorusunu tartışmaktadır. Eser içerdiği haritalar, tablolar ve Sasani tarihi çalışmaları için önemli olabilecek zengin bir bibliyografya ile sona ermektedir.

$\mathrm{Bu}$ kısa betimlemeden sonra Pourshariati'nin, Sasani İmparatorluğu'nun hızlı çöküşü için önerdiği alternatif açıklama modeline ve bu konu hakkındaki geleneksel görüşlere temas etmek yararlı olacaktır. Sasani İranı'nın “iç tarihine” yönelen Pourshariati, Christensen'in aksine, imparatorluğun merkeziyetçi bir devlet olmadığını, imparatorların güçlü bir merkezi otoriteyi hiç bir zaman mutlak manada tesis edemediklerini, onun için devletin daha ziyade konfederatif bir yapıya sahip olduğunu savunmaktadır. ${ }^{8}$ Daha eserin başlarında işe Christensen'in tezini ele alarak başlayan Pourshariati, Part aristokrasisinin devam ettiğini ve konfederasyonun, Pers kökenli (Parsig) ve Part kökenli (Pehlevi) güçlü ailelerden oluştuğu tespitini yapmaktadır. Feodal nitelikli bu ailelerin, hem kontrol ettikleri bölgelerde otonom bir idari yapıyı sürdürdüklerini hem de üst düzey devlet görevlerini ellerinde bu-

8 Bu yaklaşımı ilk dile getiren Pourshariati değildir, Zeev Rubin 2000 yılında Sasanilerin güçlü bir merkezî devlet olmadığını ifade etmişti. Zeev Rubin, "The Sasanid Monarchy," The Cambridge Ancient History, ed. A. Cameron, B. Ward-Perkins ve M. Whitby (Cambridge: Cambridge University Press, 2001), 14: 638-61.

Dîvân

$2019 / 1$ 
lundurduklarını ifade eden Pourshariati'ye göre, Sasaniler'in 224 yılında Part hanedanını ortadan kaldırmış olmaları, gerçekte Part gücünün sonu anlamına gelmiyordu ve İran dünyasının bilhassa kuzey ve doğu kısımlarında bu aileler varlıklarını rahatça sürdürüyorlardı. ${ }^{9}$ Dolayısıyla güçlü aileler arasındaki rekabet ve gerilim bütün Sasani tarihi boyunca vardı. VI. yüzyılda Mazdek krizi sonrasında tahta çıkan Hüsrev Anuşirvan'ın büyük aileleri parçalamayı amaçlayan reformları bile bu feodal yapıyı fazla zayıflatamamıştı. İktidar alanını daraltan bu ailelere karşı imparatorun yapabileceği en iyi şey, onları birbirine düşürmekti. Ne var ki, aristokratların kendi aralarında bir uzlaşıya vardıkları zaman, bunun kralın sonu anlamına geldiği iddiasını, Pourshariati sadece tek bir örnekle, 589 / 90'da II. Hüsrev'in iktidara gelişi sırasında çıkan Bahrâm-ı Çûbîn isyanıyla destekleyebilmektedir. Müslüman Arapların İran'da ilerleyişini kolaylaştıran faktörün de yine bu güçlü aristokrat yapı olduğunu savunan Pourshariati, bu ailelerin imparatorun yanında Araplara karşı direnmektense, onlarla anlaşma yoluna gittiklerini ve böylece güçlerini VIII. yüzyıla kadar koruduklarını ileri sürmektedir (s. 462).

Pourshariati üçüncü temel argüman olarak, Irak'taki İslam fetihlerinin kronolojisinin gözden geçirilmesini teklif etmektedir. Hicri tarihlendirmeyi yetersiz ve güvenilmez bulan yazar, İslam fetihlerinin başlangıcını 628 yılına kadar geri getirerek en az on ylllı bir revizyon önermektedir. Bu durumda fetihler, Sasani kralı II. Hüsrev'in 627 yılı sonunda Ninova'da Heraclius'a yenilmesinin hemen akabinde, yani daha Hz. Peygamber'in sağlığında başlamış oluyordu. Ancak Pourshariati, Touraj Daryaee'nin de not ettiği gibi, ${ }^{10} \mathrm{~Hz}$. Peygamber'in bu fetihlerdeki herhangi bir rolüne değinmemektedir. Mekke'nin fethinin bile gerçekleşmediği bir dönemde, Müslümanların Irak’ı fethetmelerinin mümkün olup olmadığı ayrı bir mesele. Pourshariati, fetih kronolojisindeki revizyon öne-

9 Son zamanlarda Sasani arkeolojisi üzerine yapılan ilginç bir çalışma, İran dünyasında tarımsal üretim ve kentsel yaşamı desteklemek için gerçekleştirilen alt yapı çalışmalarının ancak merkezî bir devletin otoritesiyle olabileceğini savunmakta ve federatif bir yapıda bu tür merkezi kontrol gerektiren faaliyetlerin yürütülmesinin mümkün olmadığını önemle not etmektedir. Richard Payne, "The Archaeology of Sasanian Politics," Journal of Ancient History 2 / 2 (2014): 1-13.

10Touraj Daryaee, "The Fall of the Sasanian Empire to the Arab Muslims: From Two Centuries of Silence to Decline and Fall of the Sasanian Empire: the Partho-Sasanian Confederacy and the Arab Conquest of Iran," Journal of Persianate Studies 3 (2010): 246. 
risini, Hulefa-yi Raşidin döneminde meydana gelen "ridde" ve fetihler üzerine bilhassa kronoloji açısından tartışmalı bir kaynak olan Seyf bin Ömer'e (ö. 796) dayandırmaktadır (ss. 166-71). Seyf bin Ömer, Taberi tarafından geniş olarak kullanılmış olmakla birlikte, XIX. yüzyılın sonunda başta Julius Wellhausen olmak üzere, bazı Oryantalistler ve Müslüman İslam tarihçileri tarafından güvenilmez bulunuyordu. Ancak İslam tarih yazımındaki tartışmalı konumundan ötürü ilgi odağı olmayı sürdüren Seyf'e yönelik yaklaşımlar daha pozitif bir yöne doğru gitmektedir. ${ }^{11}$

Pourshariati'nin eserinin ikinci kısmı temel argümanıyla ilgisiz gibi görünse de esas itibarıyla İran'daki örgütlü dinî yapının Sasani İmparatorluğu'nun çöküşündeki rolünü ele alması bakımından dikkate değerdir. Buna göre, İslam fetihlerinin hemen öncesinde İran dininin durumunu ayrıntılı bir şekilde inceleyen yazar, Sasani Zerdüştlüğü ile Part Zerdüştlüğü arasında bir ayrışmayı tespit etmektedir. Bilhassa, İran'ın kuzey ve doğu kısımlarında Mithra dininin (Mihr) süregiden popülaritesine dikkat çekmekte ve II. Hüsrev'i tahttan atmak için çıkan Bahrâm-ı Çûpîn (M.S. 590) isyanını farklılaşan bu dinî boyutla irtibatlandırmaktadır. Aynı şekilde Emevi hanedanının çöküşünde ve Abbasilerin yükselişinde çok önemli bir rol oynayan Horasanlı Ebu Müslim'in, 755'de öldürülmesinin intikamını almak için isyan eden Mithracı rahip Sunbad meselesini de Mithracılığın popülaritesi bağlamında ele almaktadır. Part coğrafyasında hiç Mithra tapınak kalıntısının bulunmadığına dikkat çeken Touraj Daryaee ise, arkeolojinin Pourshariati'yi desteklemediğine işaret etmektedir. ${ }^{12}$

Pourshariati, doğal olarak Abbasileri iktidara getiren Horasanlı Ebu Müslim’in öncülük ettiği isyanı, İranî nitelikleri ön plana çıkararak adeta bir "Pers devrimi" olarak sunmakta ve bu isyanla ilgili gruplaşmaları, İran'daki güçlü ailelerin varlıklarını sürdürmelerinin bir başka delili olarak kabul etmektedir (s. 414 vd). İslam tarih yazıcılığında çok verimli bir çalışma ve tartışma alanı olan bu mesele, J. Wellhausen'den beri “Abbasi devrimi” olarak nitelenmek-

11 Seyf bin Ömer'le ilgili tartışmalar Ella Landau-Tasseron tarafından kapsamlı olarak değerlendirilmektedir. Ella Landau-Tasseron, "Sayf Ibn 'Umar in Medieval and Modern Scholarship,” Der Islam 67 (1990): 1-26. Seyf'in sunduğu verilerin tamamen de reddedilmemesi gerektiğini savunan Landau -Tasseron'un görüşleri, büyük oranda şu çalışmada tekrar edilmektedir: Mahmut Kelpetin, “Müsteşriklerin Gözüyle Seyf b. Ömer,” Usûl İslam Araştırmaları 10 (2008): 126-40.

12Daryaee, "The Fall of the Sasanian Empire to the Arab Muslims," 250.
233

Dîvân

$2019 / 1$ 
tedir. ${ }^{13}$ İrancılık, Araplık, kabilecilik, mevali (Arap olmayan Müslümanlar), Şiilik gibi çeşitli argümanların ileri sürüldüğü “Abbasi devriminde” aslan payının İranlılara mı yoksa Araplara mı verileceği sorunu da uzun zamandır tartışmanın "verimli” özünü oluşturmaktadır. ${ }^{14}$ İsyandaki Arap faktörü en güçlü biçimde vurgulayan M. A. Shaban, meseleyi 1970'de bir "Pers devrimi” veya mevali isyanı olarak değil, belkemiğini Merv civarına yerleştirilen Arap köylülerinin (bölgeye gelen ilk askeri kuşağın temsilcileri) oluşturduğu bir "Arap devrimi” olarak görmüştü. ${ }^{15}$ Pourshariati, "Abbasi Devrimine” bir bölüm ayırmış olmasına karşın (ss. 414-26), bibliyografyasında veya dipnotlarında, Shaban'ın bu önemli eserine yer vermemesi bir eksiklik olarak değerlendirilmelidir.

Çağdaş tarih yazımında Sasani İmparatorluğu'nun nasıl çöktüğü meselesi, yaygın olarak VI. yüzyılın ortalarından itibaren Bizanslılarla giriştikleri savaşlarla ilişkilendirilmektedir. I. Hüsrev (531-79) ve çağdaşı Bizans imparatorları (Justinianus, II. Justinus, Tiberius) arasındaki savaşlar ve bilhassa "Antikçağın son büyük savaşı" olarak nitelenen II. Hüsrev döneminde yapılan savaşların yıpratıcı etkisi sıklıkla ileri sürülmektedir. Son dönemlerde yine 540'lı yıllarda başlayan veba salgınının ve bir dizi depremin de rolüne dikkat çekilmektedir. Keza Josef Wiesehöfer'in özetlediği, bilhassa 627'de Ninova'da Heraclius'a karşı kaybedilen savaşın yarattığı siyasi kriz

13 Kavram ilk kez Julius Wellhausen tarafından kullanılmıştır. J. Wellhausen, The Arab Kingdom and its Fall, çev. Margaret G. Weir (Calcutta: University of Calcutta, 1927), 556. Merhum Fikret Işıltan, Wellhausen'in "revolution/devrim" terimini "değişiklik" gibi sıradan bir kelimeyle karşılamıştır. J. Wellhausen, Arap Devleti ve Sukutu, çev. Fikret Işıltan (Ankara: Ankara Üniversitesi Illahiyat Fakültesi, 1963), 263.

14H. A. R. Gibb, The Arab Conquests in Central Asia (Londra: The Royal Asiatic Society, 1923); Khalid Yahya Blankinship, "The Tribal Factor in the 'Abbasid Revolution: The Betrayal of the Imam Ibrāhīm b. Muhammad," Journal of the American Oriental Society 108/4 (1988): 589-603; Said Amir Arjomand, "AAbd Allah Ibn al-Mukaffa and the "Abbasid Revolution," Iranian Studies 27/1-4 (1994): 9-36; Roberto Marin-Guzman, Islamic Studies 33/2-3 (1994): 227-52; Saleh Said Aghe, The Revolution Which Toppled the Umayyads Neither Arab nor 'Abbāsid (Leiden: Brill, 2003).

15Muhammad A. Shaban, The 'Abbâsid Revolution (Cambridge: Cambridge University Press, 1970). Bu konu üzerine yapılan en son ayrıntılı yayında Étienne de la Vaissière, Çin kaynaklarını ve arkeolojik materyali dikkate alarak, Abbasi ihtilalini genelde Arap komutanların idaresindeki İranlıların eseri olduğunu savunmaktadır. Étienne de la Vaissière, "The 'Abbasid Revolution in Marw: New Data," Der Islam 95/ 1 (2018): 110-46. 
de önemlidir. ${ }^{16}$ Zira bu kriz hemen çözülemedi ve 628'de Hüsrev'in öldürülmesiyle 633'de III. Yezdigerd'in tahta geçişi arasındaki beş yılda ikisi kadın sekiz imparatorun iş başına gelmiş olması siyasi krizin derinliğini yeterince açıklamaktadır.

Sasani İmparatorluğu'nun ani çöküşünde, II. Hüsrev'in Hristiyan olan Irak'taki son Lahmi kralı Numan'ı Bizans ile bir ittifaka gireceği endişesiyle 602 yılında öldürtmesi ve krallığını lağvetmesi de önemlidir. Bu durum Arap yarımadasıyla İran arasındaki Mezopotamya sınırını yumuşatmış ve yaklaşık otuz yıl sonra İslam akınları başladığı zaman, savunmasız kalan Mezopotamya sınırından Arapların geçişini kolaylaştırmıştı. Sasaniler'in yıkılışını İran'ın iç dünyasındaki sorunlara bağlayan Pourshariati, doğal olarak İslam dininin Araplarda yarattığı enerjiyi ve organizasyon kapasitesini göz ardı etmektedir. Bu şüphesiz bilinçli bir tercih, çünkü Daryaee'nin not ettiği Pourshariati'nin esas başarısı, Arap-İslam merkezli bir İran tarih yazımından İran merkezli bir tarih yazımına geçişi önermesindedir.

Pourshariati'nin devasa eserini hem okumak hem de bütün yönleriyle değerlendirmek çok kolay değil. Sasani tarihini "konfederasyon” kavramı çerçevesinde gören yazar, aslında farklı kültürel geleneklerin arasındaki iş birliğine dikkat çekmektedir. Çünkü her ne kadar Pourshariati, Sasani devletinin çöküşüne odaklanmış görünüyorsa da aslında konfederatif yapının Eskiçağda Sasani devletini dört yüz yıl gibi uzunca bir süre nasıl ayakta tuttuğunu düşünmemizi de istemektedir. Böylece, Pourshariati'nin eserinin gerisinde, tek biçimli modern İran dinî ve siyasi ideolojisine bir eleştiri düşüncesi olduğunu görmek de mümkündür.

Edinburgh Üniversitesi yayınlarının 2014 yılında başlattığı Edinburgh Studies in Ancient Persia serisine geçtiğimiz yll iki önemli eser daha dahil oldu. Bunların ilki Eberhard W. Sauer'in editörlüğünü yaptığı Sasanian Persia Between Rome and the Steppes of Eurasia 2013 yılında düzenlenen “The Sasanian Empire and Rome" başlıklı çalıştaya dayanmaktadır. Ana hatlarıyla ifade etmek gerekirse, dört genel tema altında "giriş" dahil on iki bildiriden oluşan bu eserin ilk kısmı Sasani İmparatorluğu'nda kentleşme olgusu ve kent ekonomisini, İran coğrafyasının kırsal üretim tekniklerini

16 Josef Wiesehöfer, "The Late Sasanian Near East," The New Cambridge History of Islam, vol. 1: The Formation of the Islamic World Sixth to Eleventh Centuries, ed. Chase F. Robinson (Cambridge: Cambridge University Press, 2010), 98-152. 
ve asgari geçim imkânlarını ve bir geçim ve gıda maddesi kaynağı olarak hayvancılık meselesini ele almaktadır. Arkeolojik veriler esasında kaleme alınan pek çok makalede aşina olduğumuz "çok yazarlı" durum burada da karşımıza çıkmaktadır. St. John Simpson ilk bölümde sadece bilinen kentleri değil, aynı zamanda uydu resimleme tekniklerinin desteğiyle ulaşılan yeni keşifleri de listeye eklemektedir (ss. 21-50). ${ }^{17}$ Roma dünyasında (bilhassa Batı'da) V. yüzyılda kentleşme ciddi bir gerileme içerisindeyken, İran'da kayda değer bir canlanma tespit edilmesi ve özellikle bazı askerî merkezlerin zamanla kente dönüşmesi dikkat çekicidir. Eserde yer alan ikinci mesele, bir Eskiçağ imparatorluğunun "temel gıda maddelerinin üretimini” ve bunların dolaşımını nasıl sağladığıdır. Bu mesele, Sasanilerin ekonomik ilişkilerini anlamamıza yardımcı olduğu gibi, Sasani devletinin doğası hakkında da fikir vermektedir (ss. 51-73). Büyük sıçramaların yaşanmadığı Eskiçağ İran dünyasının ekonomisi, Perslerden Sasanilere kadar çok geniş bir kronolojik ve coğrafi spektrumda ele alınmaktadır. Aynı şekilde kendi gıdasını üretmeyen İranlı kentli nüfusun beslenmesi meselesinde, ayrıntılı ve kontrollü bir dolaşım organizasyonuna olan ihtiyaca işaret edilmektedir. Bu kısmın son teması, arkeolojik buluntuların sağladığı imkanlar çerçevesinde, sınırlardaki asgari hayat standardı ve gündelik hayatın sürdürülebilirliği için Hazar denizi ve Elbruz dağları arasındaki Cürcân (Hyrcania veya Gürgan) ve Deriali kaleleri gibi yerleşimlerdeki "hayvancıllk" meselesidir (ss.74-95).

Sasanilerin kontrol ettiği İran coğrafyası, Asya ile Avrupa arasında bir kara köprüsü olarak çeşitli imkanlara sahip olduğu gibi tehditlere de açıtıt. Sınırlar ve sınır manzaraları çerçevesinde ele alınan ikinci kısımda, "Sâsânî İmparatorluğu'nun Kuzey ve Batı Sınır Bölgeleri: Roma/Bizans ve Sâsânî Sınırının bir Bağlama Yerleştirilmesi," "Bir Sasani Sınırının Bağlantı Sağlayabilme Kapasitesi: Kuzeydoğu İran'ın Cürcân Ovasında Yol Sistemi," "Sâsânî İmparatorluğu ve Doğu: Verilerin Bir Özeti ve Roma İçin Çıkarımlar” gibi alt başlıklardaki konular tartışılmaktadır.

Roma ve İran arasında tartışmalı toprakların ve kültürel irtibatların ele alındığı üçüncü kısım, "Sasani İmparatorluğu'nda Azınlık dinleri: Baskı, Entegrasyon ve Roma ile İlişkiler,” “Tartışmalı

17St. John Simpson, "Merv, an Archaeological Case-Study from the Northeastern Frontier of the Sasanian Empire," Journal of Ancient History 2/2 (2014): 1-28; Ali Mousavi ve Touraj Daryaee, "The Sasanian Empire: An Archaeological Survey, c. 220-AD 640," A Companion to the Archaeology of the Ancient Near East, ed. Daniel T. Potts (West Sussex: Wiley-Blackwell, 2012), 2: 1076-1094. 
bir yetki bölgesi: Geç Antikçağda Ermenistan” ve “I. Ardeşir (M.S. 224-40) Zamanında Roma ve İran Arasında Kültürel İrtibatlar” incelenmektedir. Lee Patterson, Sasani İmparatorluğu'nda azınlık dinlerinin durumunu "dinsel tolerans" problematiği çerçevesinde incelemektedir. Bu mesela daha yakın zamanlarda Richard Payne tarafından kapsamlı bir çalışmada ele alınmıştı. ${ }^{18}$ Meşhur Zerdüşt başrahip (movbedân-l movbed) Kerdir'in yazıtında ima edilen kapsamlı bir Zerdüştleştirme politikası ve "Hristiyan fanatiklerin biyografilerinde” yer alan detaylara karşın, Patterson, Sasani İmparatorluğu gibi önemli kaynaklara hükmeden bir devletin, azınlık dinlerinin kökünü kazımak için heveskar bir politika izlemediğini ve bunun için bir nedeninin olmadığını savunmaktadır (ss. 18198). Gerçekten yukarıda söz konusu edilen Richard Payne'nın çalışması da kendisinden başkasına hayat hakkı tanımayan katı Zerdüştlük imajını bir mit olarak nitelendirmekte ve Sasani İranı'nın belirgin Zerdüştlüğünün yanı sıra, Hristiyan, Yahudi ve sair pagan kültlerin karması bir toplum olarak ele almaktadır. Hiç şüphesiz bu yaklaşım İran'da Hristiyanların zaman zaman kovuşturuldukları gerçeğini örtmemektedir. Ancak bu münferit kovuşturmaların hem fanatik Hristiyanların ölçüsüz eylemleri hem de Sasani-Roma ilişkilerinde yaşanan siyasi gerilimlere paralel olduğuna dikkat çekilmektedir. Gerçekten de 410 yllında Ctesiphon'da (Medain) toplanan bir kilise konseyinin patronunun "İran'ın Constantinus'u" olarak nitelenen Sasani kralı I. Yezdigerd'in olması önemlidir. Dolayısıyla İran'da Hristiyanların kovuşturulması meselesi, daha ziyade sorun çıkaranlarla sınırlıdır.

Eskiçağ Ermenilerinin Roma ve İran arasında tampon toplum oldukları ve Hristiyanlaşmalarıyla birlikte kültürel ve siyasal olarak Sasaniler'den uzaklaşarak, Roma / Bizans dünyasının siyasi ve kültürel kodlarına yakınlaştıkları genel bir kabuldür. Diğer yandan Antikçağda Ermenilerin yaşadığı coğrafyanın büyük bir kısmı da İran tarafından kontrol edilmekteydi. Ermeniler, Hristiyanlaşmalarına karşın miafizit (monofizit) mezhebe dahil olarak Bizans İmparatorluğu'nun resmî ideolojisinden; kendi alfabelerini geliştirerek de miafizitliği benimsedikleri Süryanilerden uzaklaşarak özgün kimliklerini biçimlendirmeye çalışmışlardır. Tim Greenwood çok farklı bir konuyu ele aldığı araştırmasında, Ermeni hukuku üzerinde Sasani etkisini tartışmakta ve İran nüfuzunun Roma'dan çok daha köklü olduğuna işaret etmektedir. Greenwood'un maka-

18Bkz. dipnot 2. 
lesi ayrıca, Geç Antikçağ Ermeni kültür tarihi çalışmalarında kilise literatürünün çok da abartılı kullanılmaması gerektiği konusunda bir uyarı niteliği de taşımaktadır (ss. 199-220). Üçüncü kısmın son çalışmasında İslam öncesi İran arkeolojisinin deneyimli bir uzmanı olan Pierfrancesco Callieri, Ardeşir döneminde Fars'ta oyulan meşhur kaya kabartmasını yeniden incelemekte ve bu kurucu kralın, Sasani hanedanını bilinçli olarak ilk Pers İmparatorluğu'na (M.Ö. 550-330) dayandırdığını ileri sürmektedir (ss. 221-38). Callieri sadece materyal kalıntılarla değil, aynı zamanda literatür verilerini de dikkate alarak Sasanilerin ilk krallarının kendilerini Pers İmparatorluğu'nun hakiki vârisleri olarak sunduklarını ortaya koymaktadır. Callieri diğer yandan incelediği kaya anıtlarının sadece İranlı ustaların işi olmadığını, Ardeşir'in Mezopotamya'daki fetihleri ve Roma imparatorları ile girdikleri savaşlarda ele geçirdikleri taş ustalarının da katkısına dikkat çekmektedir. Bu faktör, kültürel çoğulculuğu başarabilme esnekliğine sahip güçlü Sasani krallarının, fethettikleri Romalılardan öğrenme kapasitelerini göz ardı etmediklerini göstermektedir.

Dördüncü ve son bölüm, Sasani İran'ını “Emperyal Güç Dengesi ve Uluslararası İlişkiler” bağlamında ele almaktadır. İran'ın üç dünyası; Roma, Arap Yarımadası ve Hindistan bu bölümün temel çerçevesi olarak tespit edilmektedir. "Yenilik ve Durgunluk: Roma ve İran Arasında Askeri Altyapı ve Güç Dengesinin Değişimi” başlığı altında yazarlar, Sasani ve Roma askerî alt yapılarını karşılaştırmalı olarak incelemektedirler. Mevcut arkeolojik materyal, Hazar'ın batı ve güney kıyılarındaki geçiş alanlarında Sasanilerin IV- VI. yüzyıllar arasında, Geç Antikçağ dünyasının en gelişmiş savunma sistemini nasıl inşa ettiklerini göstermektedir. Bu savunma sistemi içinde, Cürcan surları gibi neredeyse 200 km'ye ulaşan gelişmiş bir yapı ve Kafkaslarda geçitleri tutmak için inşa edilen istihkâmlar (limes) ve bariyerler yer alıyordu. Halbuki aynı dönemde Roma İmparatorluğu'nun Germenler ve Hunlarla olan kuzey sınırları ve istihkâmları çökmüştü. Sasanilerin o yüzyıllardaki askeri alt yapıyı ve savunma sistemini geliștirme atılımları zorunluluktan kaynaklanıyordu. Çünkü bu sistem aynı zamanda kuzeyden gelen Hunların, Ak Hunların ve daha sonra da batı Göktürklerin yarattığı tehlikenin büyüklügünü de ortaya koymaktadır.

Craig Morley, Geç Antikçağ İran'ının Mezopotamya ve Basra körfezinin batısında yer alan Arap sınırının, Sasani İmparatorluğu için önemini bir "temel taş” olarak nitelendirmekte ve bu temayı “imkanlar ve tehditler” veya bir başka deyişle ekonomik ilgiler ve 
askerî güvenlik çerçevesinde araştırmaktadır (ss. 268-83). Roma İmparatorluğu'nun epey periferisinde kalan Arap yarımadası, Sasani İranı için neredeyse merkezi bir öneme sahipti. Bunun içindir ki, I. Şapur'un meşhur yazıtında Umman (Mazun) bile imparatorluğun “ayrılmaz bir parçası” olarak nitelenmektedir. Basra körfezinin Sasani İmparatorluğu tarafından denetlenmesi, körfezin sağladığı kârlı bir ticaretin kontrolü olarak değerlendirilmekte ve Touraj Daryaaee'nin işaret ettiği Basra körfezinin Sasani mare nostrum'u (bizim deniz) olduğu fikri çerçevesinde ele alınmaktadır. ${ }^{19}$ Bölümde ayrıca Sasaniler açısından Arap sınırının sebep olduğu tehdit ve bu tehdide karşı İran'ın Lahmiler (Nasriler) ile kurduğu ittifak tartışılmakta ve bu tampon krallığın 602'de ortadan kaldırılmasının İran dünyası için yıkıcı etkisine dikkat çekilmektedir. Morley'in, Lahmilerin merkezi Hire kenti üzerine son zamanlarda yazılmış önemli ve daha kapsamlı bir makaleye bibliyografyada yer vermemesi bir eksiklik olarak görülebilir. ${ }^{20}$ Lahmi sınırının gevşemesi önemlidir ama daha da önemli olan, Arap yarımadasının kendi iç enerjisi ve organize olabilme kapasitesidir. Morley bu bölümü kaleme alırken, sikke buluntularına vurgu yapmaktadır. Ancak neredeyse dört yüz elli yıllık bir imparatorluğun bölgedeki varlığını ve ağırlığını göstermek için söz konusu edilen sikke miktarı (toplam 47) çok kısıtlıdır ve aynı dönemde bölgede bulunan Roma/ Bizans sikkeleri ile bir karşılaştırılması yapılmamaktadır. Sikke dolaşımının potansiyel olarak çok şey anlatabileceği kuşkusuzdur, fakat bu kadar kısıtlı bir miktardaki sikkenin bölgeye ticari yollarla mı yoksa askerî operasyonlar neticesinde mi ulaştığı belirsizdir.

Sasani tarihi üzerine çok önemli bir uzman olan James HowardJohnston, son bölümde Sasani İmparatorluğu'nun Hint Okyanusu ticaretindeki yerini değerlendirmektedir. Howard-Johnston'ın perspektifi sadece İran ve Hint dünyasıyla sınırlı değildir ve İskandinavya'dan Çin'e, Akdeniz'in bir ucundan Orta Asya'ya veya Afrika'ya kadar çok daha geniş bir dünyada Sasanilerin ticari izlerini sürmektedir. Howard-Johnston, Sasani imparatorlarının bu devasa coğrafyadaki karmaşık deniz ticaret ağını nasıl yönettiklerini ve bu ticari ağ vasıtasıyla ipek, buhur, lal taşı gibi ürünlerin Avrupa'nın pek çok köşesine nasıl ulaştığı meselesini, aynı zaman-

19Touraj Daryaee, “The Sasanian 'Mare Nostrum': The Persian Gulf,” International Journal of the Society of Iranian Archaeologists 2/3 (2016): 40-6.

20 Isabel Toral-Niehoff, "Late Antique Iran and the Arabs: The Caese of alHira,” Journal of Persianate Studies 6 (2013): 115-26.
239

Dîvân

$2019 / 1$ 
da Bizans, İran ve Türkler arasındaki rekabeti de dikkate alarak çok maharetle özetlemektedir. Ayrıca, Geç Antikçağda Sasani tüccarların ipek ve buhur gibi müşterisi geniş ürünlerin yanı sıra, Hindistan ve Sri Lanka'dan getirdikleri lal taşı gibi lüks tüketim ürünlerine de dikkat çekmektedir. Bilhassa Sasanilerin 571 yılında Yemen'i kontrol etmeleriyle birlikte bu bölgedeki Roma tüccar gemileri üzerindeki sıkı denetimi de dikkate alarak 570'li yıllardaki Batı Göktürkleri ile Bizans arasındaki yakınlaşmayı, Yemen ve bloke edilen Bizans ticari güzergahı arasındaki bağlara dikkat çekmektedir.

Sasanian Persia Between Rome and the Steppes of Eurasia'daki makaleler, Sasani İmparatorluğu'nu federatif bir yapı değil, tam tersine emperyal programı olan merkeziyetçi bir devlet olarak sunmaktadır. Araplarla olan ilişkilerin bozulmasının yarattığı yıkıcı etkilere dikkat çekilmesi bir anlamda Sasani İmparatorluğu'nun yıkılışındaki geleneksel görüşü, yani Arap sınırının zayıflaması meselesini yeniden hatırlatmaktadır. Dolayısıyla bu makale derlemesi, neredeyse Pourshariati'nin ortaya sürdüğü tezlere bir reddiye veya karşı görüş (challenge) gibi görünmektedir. Diğer yandan Sauer'in editörlüguünde hazırlanan bu çalışmalar, klasik yazılı literatürün yanı sıra modern teknolojinin sağladığı imkanları da kullanarak, saha araştırmaları, arkeoloji, nümizmatik, sigillografi (mühür bilimi) gibi çok geniş bir veri yelpazesinden beslenmektedir. Sonuçta, bu zengin birikim, karşılaştırmalı okunduğu zaman, edebî metinlere fazlaca bağımlı görüşlerin daha ayrıntılı tartışılmasına imkan sağlamakta ve Sasani İmparatorluğu'nu merkezî yapısı güçlü bir devlet olarak gören Christensen'in tezini yeniden ayakları üzerine dikmeye teşebbüs etmektedir.

Sasani İmparatorluğu, modern tarih yazımında daha çok batıya dönük bir devletmiş gibi görünmektedir. Bunun bir nedeni, tarih yazımında popüler "doğu-batı çatışması" modelinin cazibesidir, çünkü Sasani-Roma ilişkileri bu model için bir enstrüman haline getirilme potansiyeline sahiptir. ${ }^{21}$ Diğer yandan klasik Yunan-Roma kaynaklarının sunduğu imkanların izinden giden çalışmaların ekseriyetinin Roma-İran ilişkileri üzerine odaklanmasıdır. ${ }^{22}$ Kho-

21 Geo Widengren, "Iran, der grosse Gegner Roms: Königsgewalt, Feudalismus, Militärwesen," Aufstieg und Niedergang der römischen Welt, ed. Hildegard Temporini (Berlin: DeGruyter, 1976), 219-306; Beate Dignas ve Engelbert Winter, Rome and Persia in Late Antiquity, Neighbours and Rivals (Cambridge: Cambridge University Press, 2007).

$22 \mathrm{Michael} \mathrm{H.} \mathrm{Dodgeon} \mathrm{ve} \mathrm{Samuel} \mathrm{N.C.} \mathrm{Lieu,} \mathrm{The} \mathrm{Roman} \mathrm{Eastern} \mathrm{Frontier} \mathrm{and}$ the Persian Wars AD 227-363, A Documentary History (Londra: Routledge, 1991). 
dadad Rezakhani'nin ReOrienting the Sasanians, East Iran in Late Antiquity adlı eseri, daha başlıkta İran-merkezli bir perspektifi ortaya koymaktadır. Türk tarih yazımında bu bölgeler yaygın biçimde Orta Asya olarak adlandırılmaktadır.

Edinburgh Studies in Ancient Persia serisinin önemli bir halkasını oluşturan ve yukarıda ele alınan iki esere nispeten çok daha kısa, ancak kronolojik çerçevesi daha geniş olan Rezakhani'nin bilhassa nümizmatik verileri öne çıkaran ve kronolojik olarak tasarlanmış eseri, "Giriş" bölümü dışında on bir bölümden oluşmaktadır. Bu eser, en genel ifadeyle, M.S. I-VIII. yüzyıllar arası Doğu İran tarihi ve coğrafyasında etkili olan siyasi yapılar ve bunların Sasanilerle ilişkileri üzerine genel gözlemler olarak da nitelenebilir.

Sasani devletinin kurucusu Ardeşir'in (ö. 242) Horasan'ın güneyinde yer alan Sistan veya Sakastan bölgesine gelişi ve buradaki fetihleriyle ilgilenen "Sâsânîler ve Sistanlılar" başlıklı ilk bölüm, ön bilgi olarak Sistan'ın İndo-Partlarla bağlantısına ve Kuşhanların, I. yüzyılda Sakaların dünyasına girişine temas etmektedir. Rezakhani bu bölgeyi, Sasani krallarının kimliğinin oluşumunda belirleyici olan İndo-Part ve İndo-Saka kaynaştırma potası olarak görmektedir. Diğer yandan Sistan / Sakastan bölgesinin Sasaniler tarafından fethinin esas önemi, burasının Doğu İran'ın fethi için bir basamak işlevi görmesidir. Bilindiği gibi Türk mitolojisinde çok önemli bir yer tutan, İran-Turan savaşlarının kahramanı Alp Er Tunga (Şâhnâme'de Afrasyab) Sakaların hükümdarıydı. İkinci bölümde Sasaniler'in Baktria'da (Tohâristan) Kuşhanlarla karşılaşmasını ve bu güçlü krallığın çöküşüne kadar kısa bir özetini sunan Rezakhani, daha sonra Doğu İran'da Kuşhan-Sasani hanedanıyla ilgilenmekte ve hakkında çok az bilgi sahibi olunduğunu düşündügü bu hanedanla ilgili problemleri tartışmaktadır. Sonraki bölümde, Khionit Hunlarının Doğu İran’ı işgallerinin hikayesini ve Baktria'nın kontrolünü ele geçiren ve güneye Hindikuş bölgesine doğru genişleyen ilk hanedan olan Kidaritlerin ortaya çıkışını ele almaktadır. Romalı tarihçi Ammianus Marcellinus'un (ö. 390’lar) aktardığına göre, Khionit Hunları 359 yılında Sasanilerin Diyarbakır kuşatmasına da yardımcı olmuşlardı. Eserin beşinci bölümü, Khionit Hunlarının bir uzantısı olan Alkhanların, bugünkü Afganistan'da yer alan Kabulistan, Zabulistan ve Kandahar bölgesinin kontrolünü ele geçirmelerinin hikayesini anlatmaktadır. Altıncı bölüm tamamen Ak Hunlar veya Eftalitlerle ilgilenmektedir. Köken olarak Moğol, Himalayaların yerlisi veya Türk oldukları tar-
241

Dîvân

$2019 / 1$ 
tışılan Ak Hunlar, Tohâristan ve Soğd bölgesinin hakimiydiler. ${ }^{23}$ VI. yüzyılın en önemli tarihçisi Prokopios'un aktardıklarına göre, Ak Hunlar kent kültürüne sahip ve teşkilatlı bir toplum olarak diğer Hunlardan ayrılıyorlardı. Sasani kralı Firuz'u 468'de ve 484'de iki defa yenerek İran'da taht meselelerine müdahale eden Ak Hunlar, V. yüzyılın ikinci yarısında Sasanilerin siyasi kaderinde belirleyici olmuşlardı (Prokopios, Savaşlar 1.3.1-7). Ancak ertesi yüzyılda Batı Göktürkleriyle Sasaniler arasında gelişen iş birliği Ak Hunların sonunu hazırlamıştı (M.S. 560). Bu meseleye Türk tarihçiliği de çok yabancı değildir. ${ }^{24}$ Yedinci bölüm herhangi bir hanedanla ilgilenmekten ziyade coğrafi bir bölge olarak Kidarit ve Ak Hunlar döneminin Sogdiana'sına ayrılmıştır. Soğd bölgesinin tarihi, Orta Asya'nın diğer kısımlarına nispeten daha iyi bilinmektedir. ${ }^{25}$ Rezakhani, Maveraünnehir, Tohâristan ve Horasan bölgelerini Kuşhanların varisleri olarak değerlendirmektedir. Kitabın sekizinci bölümü, Nîzek hanlığı ve Batı Göktürkleri üzerine odaklanmaktadır. Bu iki hanedan, Sasani kralı I. Hüsrev ile işbirliği içerisinde 560 yılında Ak Hunları ortadan kaldırmalarından sonra daha da güçlenmişlerdi. Kabil merkez olmak üzere Afganistan'da hüküm süren Nîzek hanedanı, daha çok sikke buluntularından bilinmektedir. Rezakhani'nin naklettiğine göre, Ak Hunların bir kolu olduğu düşünülen bu hanedan hakkında yazılı kaynaklar neredeyse sessizdir. Bu hanedana mensup Nîzek Tarhan'ın Kuteybe b. Müslim tarafından idam ettirildiği Belâzurî, Taberi ve İbnü'l-Esîr gibi İslam kaynaklarınca nakledilmektedir. ${ }^{26}$ Orta Asya'dan Kafkaslara uzanan ticari güzergahları kontrol altında bulunduran ve aynı zamanda kendilerine özgü dış politika stratejileri olan Batı Göktürkleri, Ak Hunlara karşı Sasanilerle iş birliği yapmışlarsa da, Sasanilerin fazla güçlenmesini de istemiyorlardı. Göktürklerin bir süre sonra Bizans imparatoru II. Iustinus'u (ö. 578) İran'a karşı bir sefer düzenlemeye

23 Kazuo Enoki, “The Origin of the White Huns or Hephtalites," East and West 6/3 (1955): 231-37; Étienne de la Vaissiere, "Is there a 'Nationality of Hephtalites'?," Bulletin of the Asia Institute 17 (2003): 119-32.

24 Mehmet Tezcan, "Akhunlar ve Eftalitler," Hindistan Türk Tarihi Araştırmaları 1/2 (2001): 3-58; Mehmet Tezcan, "Kuşanlar, Akhunlar ve Eftalitler," Tarihte Türk-Hint İlişkileri Sempozyum Bildirileri (Ankara: Türk Tarih Kurumu, 2006), 9-56; M. Melis Çeliktaş, “Ak Hun Kültürü Üzerine,” Türk Dünyası Kültür Araştırmaları Dergisi 1 (2015): 69-77.

25Étienne de la Vaissière, Sogdian Traders, A History, çev. James Ward (Leiden: Brill, 2005).

26 Nîzek hakkında daha ayrıntılı Türkçe bir çalışma için bak. Enver Konukçu, “Bir Akhun Prensi Tarhan Nizek," Türkler 4 (2002): 305-10. 
kışkırttıkları ve Heraclius'un, II. Hüsrev'e son darbeyi vurduğu savaşta da bu iş birliğinin devam ettiği iyi bilinen hususlard $1 .{ }^{27}$ Ancak İran dünyasının batı kısmını ilgilendiren bu konuya Rezakhani doğal olarak temas etmiyor. Bu bölümde yazar ayrıca Tohâristan'daki Batı Türklerinin tarihine değinerek, Sasani dünyası içerisinde Horasan kavramının doğuşuna da temas etmekte ve tarihsel anlatı adeta İslam'ın gelişi için sahneyi kurgulamaktadır. Rezakhani kısa dokuzuncu bölümde, Tohâristan ve Soğd bölgesi hakkında bazı ayrıntılara temas etmekte ve bu bölgenin Tohâristan'la birlikte Horasan kavramı içerisine nasıl dahil edildiğine işaret etmektedir. Rezakhani onuncu bölüme Orta Asya'nın diğer uygarlık bölgelerine Ortaçağ tarih yazımında nazaran daha periferi bir konumda kaldığı gözlemiyle başlamakta ve bir dizi genelleme yapmaktadır. Ancak daha önce de ifade edildiği gibi, eserin başlığı İran-merkezci bir perspektifi ortaya koymaktadır. Son bölümde hızla XI. yüzyıl başlarına geçerek Firdevsi'nin Şâhnâme'sinin yaratıldığı kültürel dünyaya kısaca temas etmektedir.

Rezakhani'nin bölge tarihine genel bir giriş niteliği taşıyan eseri, Orta Asya dünyasının İran ile ilişkilerini bilhassa sikke buluntularını değerlendirerek bir bütün olarak sunabilmektedir. Eserin en uzun bölümü temel ve ikincil kaynaklar olarak düzenlenen kapsamlı bibliyografya, konuya ilişkin daha ileri çalışmalar yapmak isteyenler için çok değerlidir. Richard Payne'nin, Doğu İran'da Sasaniler ve farklı Türk siyasi yapılarıyla ilişkileri üzerine yeni yazdığı kapsamlı makale doğal olarak bibliyografyada yer almıyor. ${ }^{28}$ Orta Asya'daki farklı Türk hanedanlarının İran ile ilişkileri, zaman zaman kuzey komşularıyla Roma'nın münasebetlerine benzetilse de arada çok önemli bir fark vardır. Germenlerin Roma dünyasına ve "Romalılaşmaya” bakışını Ostrogot kralı Theoderik, "bütün Gotlar Romalılar gibi olmak ister” diye özetlemişti. Nitekim Roma dünyasına girdikleri zaman kültürel olarak bütünüyle Romalılaştılar. Halbuki Türk hanedanlarının yönetici elitleri, seçici davrandılar ve bazı Sasani kurumlarını benimseme noktasında esnek olduklarını

27 Göktürkler konusunda en kapsamlı Türkçe eser için bkz. Ahmet Taşağıl, Göktürkler I-II-III (Ankara: Türk Tarih Kurumu Yayınları, 2013); Peter Sarris, Empires of Faith, The Fall of Rome to the Rise of Islam, 500-700 (Oxford: Oxford Univeristy Press, 2011).

28Richard Payne, "The Making of Turan: The Fall and Transformation of the Iranian East in Late Antiquity," Journal of Late Antiquity 9/1 (2016): 4-41. 
gösterseler de kültürel olarak İranlılaşmaya pek niyetli değillerdi. Böyle bir şey de olmadı. ${ }^{29}$

Sonuç olarak, burada ele alınan üç eserin ortaya koyduğu, yaklaşım farklılıkları ve yeni ufuklar, Sasani tarih yazımına artan ilgiyi ve perspektif zenginleşmesini göstermesi açısından önemlidir. Eberhard Sauer'in derlemesi, modern teknolojinin sağladığı araçlarla desteklenmiş arkeoloji ve yan dallarının sağladığı verilerin tarih yazımında görüşlerimizi test etmek için yeni imkanlar sunması ve böylelikle disiplinler arası çalışmaların önemini ortaya koyması açısından göz önüne alınmak zorundadır. Rezakhani'nin kapsamlı yatay araştırması, Sasani tarihi çalışmalarını "Roma karşıtlığı" paradigmasından kurtarmakta, güneyde Hindikuş dağlarından kuzeyde Tarım havzasına kadar daha geniş bir dünyayla irtibatlamamız gerektiğini hatırlatması bakımından kayda değerdir. Bu iki eser, merkezî olarak örgütlenmiş bir Sasani devleti imajı yaratıyorsa da Pourshariati'nin bilhassa "konfederasyon" kavramı etrafında bir Sasani toplum ve devlet yapısı inşa etmesi büsbütün çürütülmüş de değildir. Her ne kadar şimdiye kadar söz konusu edilmemişse de İran dünyasının sonraki tarihinde daha çok bölgesel hanedanlıkların etkili olduğu gerçeği dikkate alındığı zaman, güçlü ailelerin varlıklarını sürdürdükleri bir vakıadır.

Sasani tarihinin anlaşılması ve yorumlanması konusunda farklı perspektifler sunan bu üç eser İslam tarihi, Roma / Bizans tarihi, Asya Hunlarının batıya uzanan kolları (Kidaritler, Akhunlar, Avrupa Hunları) ve Göktürklerin tarihiyle olan yakın ve karmaşı ilişkiler ağı gibi nedenlerden dolayı, Türk tarihçiliğinin de Sasani tarihiyle daha yakından ve daha ciddi ilgilenmesi gerektiğini göstermektedir. Keza modern Sasani tarihçiliğindeki çok yönlü çalışma yöntemlerinin hem tartıştığı paradigmalar hem de işaret ettiği zengin ve yenilenen veri yelpazesi açısından Türkiye'deki İslam öncesi Orta Asya Türk tarihi çalışmaları konusunda da ufuk açıcı olacağı kuşkusuzdur.

29 Orta Asya'daki farklı Türk hanedanların hem birbirleriyle hem de Roma, İran ve Çin ile siyasi ve kültürel ilişkileri hakkında önemli bir kolektif çalışma daha yeni yayınland. Nicola Di Cosmo ve Michale Maas, ed., Empires and Exchanges in Eurasian Late Antiquity, Rome, China, Iran and the Steppe, ca. 250-750 (Cambridge: Cambridge University Press, 2018). 